\title{
Assessment of Seed Vigour Tests for Relative Storability and Field Performance in Cotton
}

\author{
M.Sudharani and A.Padmasri \\ Seed Research and Technology centre, Rajendranagar, Hyderabad
}

\begin{abstract}
This experiment was carried out at Seed Research and Technology Centre, Rajendranagar, Hyderabad during 2012. Five cotton hybrid seed lots (Bharat BT-1) having differences in initial vigour was utilized for the study to identify and standardize the methods for assessing the seed vigour and storability in cotton. The seed samples were subjected to accelerating ageing for 48,72 and 96 hours at $41^{\circ} C$ and 90 per cent relative humidity. The data were collected for all seed quality parameters initially and germination test was carried out after subjecting the samples to accelerating aging and during storage as well. Simple correlation studies were carried out and observed that final count of germination was suitable for assessing the seed vigour and accelerated aging for 48 hours for estimation of storage potential of cotton seed lots.
\end{abstract}

Key words: Seed vigour, accelerated ageing, storability and cotton

\section{Introduction}

Cotton is an important commercial crop in India and contributes a major share to national economy. India ranks second in cotton production ( $22 \%$ of the global production) with the average productivity of $526 \mathrm{~kg} /$ ha. Cotton is cultivated in 9 million hectares and $70 \%$ of this area is occupied by hybrids. (Mehetre et al., 2011).Timely availability of quantitative seed is very crucial for successful hybrid seed production to farmers.

Seed vigour has been recognized as one of the important aspect of seed quality. It is known that the final destination of a seed is the field; and, therefore, the establishment of a suitable plant stand is a priority for producers. Thus, to ensure seedling emergence in the field it becomes essential to previously assess the seed vigor, aiming at identifying seed lots that present higher chance of adequately establishing in the field and provide the expected return (Otoni and Mcdonald, 2005). Although the analysis of genetic purity and germination testing are priorities in the estimation of seed cultivar potential, the vigour tests clearly identify the lots vulnerable to less than optimum soil conditions, extremes of temperature and moisture. Vigour differences in the seed is of great significance to crop establishment. So vigour tests are to be standardized which indicate the capability of seed lots to emerge in the field. Sometimes fresh and revalidated seed lots (Aged seed) may record more or less same germination but differ in vigour at laboratory and field level including seed longevity. Hence, this experiment is being proposed to find out suitable method of seed testing and appropriate seedling vigour level and to ascertain the longevity of the seed in cotton.

The assessment of seed physiological potential is usually performed through germination and vigor tests. The vigor tests are regarded as important for revealing relatively narrow variations in the different deterioration stages of the seeds of a seed lot (Baalbaki et al., 2009), whereas the germination test indicates only sharp differences on seed deterioration degree. Hence, the use of vigor tests is of large usefulness on monitoring seed performance during storage, since the drop on seed vigor precedes the viability loss. Vigor test that deserves emphasis is the accelerated aging test, which is one of the most used tests for the assessment of seed physiological potential of several plant species for providing information with high degree of consistency. Several studies have employed such test to assess vigor of cotton seeds during storage (Marcos et al., 2006; Otoni and Mcdonald, 2005: Santos et al., 2001). Hence, this study was aimed at evaluating the appropriate method for assessing the seed vigour as well to detect and storability through accelerated ageing test.

\section{Material and Methods}

The study was performed at the Seed Research and Technology Centre, Rajendranagar during 2012.The seed material used in the experiment was originated from five different seed lots of cotton hybrid namely Bharat BT- I, previously treated with the fungicide Vitavax-Thiram $200 \mathrm{SC}$, at a dosage of $250 \mathrm{~mL} .100$ $\mathrm{Kg}^{-1}$ seed. After treatment, the seeds were packaged in cloth bags and stored for eight months under ambient conditions of temperature and relative humidity. The data on different seed vigour parameters were collected during bimonthly intervals.

Germination test was conducted with three replications of 50 seeds each, and carried out inside paper towel rolls moistened with water, in a volume equivalent to 2.4 times the mass of the dry substrate, at $25^{\circ} \mathrm{C}$ for seven days. The counts of germinated seeds were performed at the fourth and seventh day after test start, following recommendations established by the Rules for Seed Testing (ISTA, 2008). Results were expressed as 
the mean percent of normal seedlings emerged to each seed lot. First germination count was computed during germination test, considering only the percentage of normal seedlings emerged at the fourth day after sowing.

Accelerated aging test was performed in transparent plastic germination boxes $(11 \mathrm{~cm} \times 11 \mathrm{~cm} \mathrm{x} 3 \mathrm{~cm})$, in which seeds were evenly distributed in single layer upon a metallic screen fastened in their inner part to hold the seeds; and then at bottom of each Gerbox were added $40 \mathrm{~mL}$ water or saturated $\mathrm{NaCl}$ (Jianhua and McDonald, 1996). Immediately after, the Gerbox were lidded and kept into a BOD chamber, set at $41{ }^{\circ} \mathrm{C}$, for 48,72 and 96hours. The field emergence and seedling vigour index (SVI) (Abdul-Baki and Anderson, 1973) were recorded. The statistical analysis was done using the procedure described by Panse and Sukhatme (1985).

\section{Results and Discussion}

By observing the seed quality parameters of five cotton seed lots, it was found that the seed lot 1 was superior among the other lots by recording higher germination per cent $(96.3)$, seedling length $(18.98 \mathrm{~cm})$ dry weight of seedlings ( $0.580 \mathrm{~g})$, seedling vigour index(54.15) and field emergence $(80.3 \%)$, followed by seed lot 2 (Table1). However, the seed lot 4 was inferior among other lots with respect to most of the seed quality parameters studied viz., germination (79.3\%), speed of germination (12.23), seedling length $(15.18 \mathrm{~cm})$, seedling dry weight $(0.534 \mathrm{~g})$ seedling vigour index $(42.38)$ and field emergence $(72.7 \%)$. Nevertheless, it is important to emphasize that this sharp decrease on germination has occurred at the end of the storage period (at 8 months). However, the seeds of lots 1, 2 and 3 assessed kept their high germination percentage, i.e., higher than the minimum percentage of 75 per cent required for the marketing of cotton seeds, thus demonstrating the high physiological potential of the seeds used in this study.

On assessing the final count of germination, it was found that there were statistically significant differences among means obtained for percent germination at the end of storage period. These results demonstrate the high potential performance of seeds, when they were germinated under favorable environmental conditions; thus hindering separation of lots into different vigor levels.

By analyzing germination of seeds of hybrid seed lots of cotton starting from initial period of storage a trend of reduction on seed germination per cent over a period of eight months was evident and significant differences in the germination among the seed lots used in the study. The seed lot 1 showed significantly superior germination per cent of 96.3 followed by seed lot 2 (93.3\%), while the seed lot 5 showed only $78.3 \%$ of germination. After a period of 8 months storage, the seed lot 1 had $79 \%$ germination followed by seed lot 2 (77\%), while the seed lot 5 had $67 \%$ of germination only (Table 2). These results prove those obtained by Damavandi et al., (2007), who have concluded that the physiological quality of sunflower seeds, were negatively affected by the advance in time of storage.

The correlation coefficient studies revealed that final count of germination had significant positive association with field emergence $(0.903 *)$, indicating that final count of germination in cotton is the method for assessment of vigour in seed lots (Table 3). Tavocoli Kaakhaki et al., (2005) based on regression tests opined that standard germination test could predict the field performance. Similarly, Damavandi et al., (2007) in their studies on forage sorghum according to correlation coefficient reported that among the vigour tests primary counting, speed of germination and cold tests had high abilities in predicting the percentage and speed of germination.

By verifying the response to test of accelerated aging, it is noticeable a decreasing trend of seed germination with advancement of accelerated aging period. That event is based on the fact that seed deterioration rate is considerably increased by their exposure to highly adverse levels of temperature and relative humidity.

Further, it was observed that, as the duration of accelerated aging advanced, the germination per cent decreased in all the seed lots. By subjecting the seed material at $41^{\circ} \mathrm{C}$ and 90 per cent relative humidity for 48 hours of accelerated aging, the seed lot 1 recorded significantly superior germination per cent of 74.7 , while the lowest was recorded by the seed lot $4(61.7 \%)$. After a period of 96 hours of accelerated aging period all the seed lots lost viability and the germination percent decreased drastically. It was noticed that accelerated aging of the seed samples for a period of 48 hours had significant positive association $\left(0.939^{*}\right)$ with germination per cent after a period of 8 months storage. It showed that accelerated aging for a period of 48 hours would be appropriate for estimation of storage potential of the seed lots. On assessing seed physiological potential through traditional accelerated aging test, other researchers have also verified reduction on vigor of cotton seeds, during storage, especially under non-controlled environmental conditions (Freitas et al., 2002; Silva et al., 2012); since under such environmental conditions, the seeds are exposed to the fluctuations of temperature and relative humidity, which also contribute to reduction of seed physiological potential. Pourhaadian and Khaajepour (2010) also conducted correlation coefficient and regression relations between seed performance and vigour tests and opined similarly. However, Mahammadreza and Babak bahari (2012) differed and reported that simple and multiple regression and correlation coefficients for predicting the relationship between laboratory tests and field performance of seed for forage crops. 


\section{Conclusions}

The final count of germination was found to be standard method for assessing the seed vigour and accelerated aging for 46 hours at 90 per cent relative humidity and $41^{\circ} \mathrm{C}$ is found to be suitable for evaluating the storability.

\section{References}

[1]. Abdul-Baki AA and Anderson J D. 1973. Vigour determination in soybean by multiple criteria. Crop Science. 13: 630-633.

[2]. Baalbaki, R, Elias, S, Marcos-Filho, J, Mcdonald, M.B. 2009.Seed vigor testing handbook. Ithaca: Association of Official Seed Analysts. 341p.

[3]. Damavandi, A Latifi ,N Dashtban, A R. 2007. Evaluation of seed vigour tests and its field efficiency in forage sorghum. Journal of Agricultural Sciences and Natural resources. 14:5, 17-24

[4]. Freitas, R.A, Dias, D.C.F.S, Cecon, P.R, Reis, M.S, Dias, L.A.S. 2002. Storability of cotton seeds predicted by vigour tests. Seed Science and Technology.30: 2, 403-410.

[5]. International Seed Testing Association. 2008. International rules for seed testing. Seed Science and Technology.13:356-513.

[6]. Jianhua, Z, Mcdonald, M.B. 1996.The saturated salt accelerated aging test for small-seeded crops. Seed Science and Technology. 25:1, 123-131.

[7]. Mahammadreza and Babak bahari. 2012. Assessment of relationship between seed vigour tests and seed field performance of some forage crops of Iran. International Journal of Agriculture and Crop Sciences. 23: 1, 1763-1766.

[8]. Marcos-Filho, J, Bennett, M.A, Mcdonald, M.B, Evans, A.F. 2006. Assessment of melon seed vigor by an automated computer imaging system compared to traditional procedures. Seed Science and Technology. 34:2, 485-497.

[9]. Mehetre, S, Pardeshi, S, Pawar, S., Gahukar, S, Chavan, U. 2011. In ovule embryo cultured hybrid between Gossypium hirsutum and Gossypium arboreum: hybridity confirmation. Journal of Cotton Research and Development, 21: 131-139.

[10]. Otoni, R.R.; Mcdonald, M.B. 2005.Moisture and temperature effects on maize and soybean seedlings using the seed vigor imaging system. Seed Technology.27:2, 243-247.

[11]. Panse, V G, Sukhatme P V. 1985. Statistical methods for agricultural workers, ICAR, New Delhi, pp: 327-340.

[12]. Porhadian H, Khajepour ,M R. 2010. Relationship between germination test and field emergence in wheat. Asian Journal of Applied Sciences.

[13]. Santos, J.F, Alvarenga, R.O, Timóteo, T.S, Conforto, E.C, Marcos Filho, J, Sako, Y, Mcdonald, M.B, Fujimura, K, Evans, A.F, Bennett, M.A.2001. A system for automated seed vigour assessment. Seed Science and Technology. 29: 3, 625-636.

[14]. Silva, C.B, Lopes, M.M, Marcos-Filho, J, Vieira, R.D. 2012.Automated system of seedling image analysis (SVIS) and electrical conductivity to assess sun hemp seed vigor. Revista Brasileira de Sementes.34:1, 55-60.

[15]. Tavacoli H, Behesti A, Nasirimhalati M.2005.Assessment of seed alfalfa quality by seed tests. Journal of Agronomic Research. 3 (1):25-32.

Table 1. Seed quality parameters of cotton hybrid seed lots

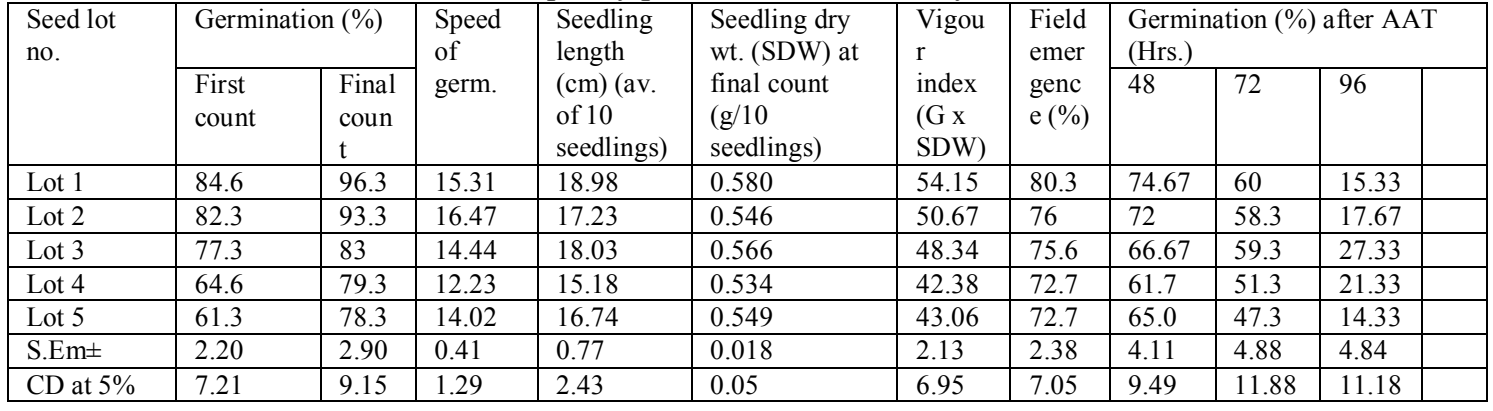


Table 2. Germination percentage of hybrid cotton seed lots during storage.

\begin{tabular}{|l|l|c|c|c|c|c|}
\hline Hybrid & Seed lot & \multicolumn{5}{|c|}{ Germination (\%) during storage (months) } \\
\hline & & 0 & 2 & 4 & 6 & 8 \\
\hline & Lot 1 & 96.3 & 90.33 & 87.33 & 85.0 & 79.0 \\
\hline & Lot 2 & 93.3 & 86.33 & 83.30 & 81.6 & 77.0 \\
\hline & Lot 3 & 83 & 79.3 & 79.30 & 82.3 & 75.0 \\
\hline & Lot 4 & 79.3 & 84.3 & 77.0 & 82.0 & 72.6 \\
\hline S.Em \pm & Lot 5 & 78.3 & 76.67 & 79.33 & 73.6 & 67.0 \\
\hline $\begin{array}{l}\text { CD at } \\
5 \%\end{array}$ & & 2.90 & 4.39 & 2.71 & 2.87 & 1.08 \\
\hline
\end{tabular}

Table3: Correlation coefficients between seed quality parameters under ambient storage of seed lots.

\begin{tabular}{|c|c|c|c|c|c|c|c|c|c|c|c|c|c|c|}
\hline $\begin{array}{l}\text { Para- } \\
\text { mete } \\
\mathrm{r}\end{array}$ & $\mathrm{X}_{1}$ & $\mathrm{X}_{2}$ & $\mathrm{X}_{3}$ & $\mathrm{X}_{4}$ & $\mathrm{X}_{5}$ & $\mathrm{X}_{6}$ & $\mathrm{X}_{7}$ & $\mathrm{X}_{8}$ & $\mathrm{X}_{9}$ & $\mathrm{X}_{10}$ & $\mathrm{X}_{11}$ & $\mathrm{X}_{12}$ & $\mathrm{X}_{13}$ & $\mathrm{X}_{14}$ \\
\hline $\mathrm{X}_{1}$ & $\begin{array}{l}1.00 \\
0\end{array}$ & $\begin{array}{l}0.924 \\
*\end{array}$ & $\begin{array}{l}0.78 \\
8\end{array}$ & $\begin{array}{l}0.77 \\
8\end{array}$ & 0.659 & $\begin{array}{l}0.968^{*} \\
*\end{array}$ & $0.893 *$ & $\begin{array}{l}0.958 \\
* *\end{array}$ & 0.067 & $0.924 *$ & 0.702 & 0.812 & $\begin{array}{l}0.75 \\
5\end{array}$ & 0.941 \\
\hline $\mathrm{X}_{2}$ & & 1.000 & $\begin{array}{l}0.80 \\
4\end{array}$ & $\begin{array}{l}0.70 \\
3\end{array}$ & 0.580 & $0.951 *$ & $0.903 *$ & 0.788 & -0.299 & $\begin{array}{l}1.000^{*} \\
*\end{array}$ & 0.836 & $\begin{array}{l}0.939 \\
*\end{array}$ & $\begin{array}{l}0.64 \\
9\end{array}$ & 0.873 \\
\hline $\mathrm{X}_{3}$ & & & $\begin{array}{l}1.00 \\
0\end{array}$ & $\begin{array}{l}0.69 \\
6\end{array}$ & 0.461 & 0.802 & 0.639 & 0.631 & -0.274 & 0.804 & 0.372 & 0.764 & $\begin{array}{l}0.20 \\
8\end{array}$ & 0.563 \\
\hline $\mathrm{X}_{4}$ & & & & $\begin{array}{l}1.00 \\
0\end{array}$ & $\begin{array}{l}0.956 \\
*\end{array}$ & 0.872 & 0.875 & 0.732 & -0.074 & 0.703 & 0.330 & 0.803 & $\begin{array}{l}0.39 \\
2\end{array}$ & 0.599 \\
\hline $\mathrm{X}_{5}$ & & & & & 1.000 & 0.776 & 0.852 & 0.665 & -0.023 & 0.583 & 0.312 & 0.722 & $\begin{array}{l}0.42 \\
6\end{array}$ & 0.539 \\
\hline $\mathrm{X}_{6}$ & & & & & & 1.000 & $\begin{array}{l}0.964 * \\
*\end{array}$ & $\begin{array}{l}0.885 \\
*\end{array}$ & -0.123 & $0.951^{*}$ & 0.704 & $\begin{array}{l}0.922 \\
*\end{array}$ & $\begin{array}{l}0.66 \\
7\end{array}$ & 0.879 \\
\hline $\mathrm{X}_{7}$ & & & & & & & 1.000 & 0.825 & -0.164 & $0.903^{*}$ & 0.742 & $\begin{array}{l}0.927 \\
*\end{array}$ & $\begin{array}{l}0.69 \\
9\end{array}$ & 0.849 \\
\hline $\mathrm{X}_{8}$ & & & & & & & & 1.000 & 0.337 & 0.788 & $\begin{array}{l}0.610^{*} \\
*\end{array}$ & 0.643 & $\begin{array}{l}0.83 \\
6\end{array}$ & 0.939 \\
\hline $\mathrm{X}_{8}$ & & & & & & & & & 1.000 & -0.299 & -0.259 & -0.489 & $\begin{array}{l}0.35 \\
6\end{array}$ & 0.156 \\
\hline $\mathrm{X}_{8}$ & & & & & & & & & & 1.000 & 0.836 & 0.939 & $\begin{array}{l}0.64 \\
9\end{array}$ & 0.873 \\
\hline $\mathrm{X}_{8}$ & & & & & & & & & & & 1.000 & 0.730 & $\begin{array}{l}0.79 \\
7\end{array}$ & 0.840 \\
\hline $\mathrm{X}_{8}$ & & & & & & & & & & & & 1.000 & $\begin{array}{l}0.47 \\
0\end{array}$ & 0.713 \\
\hline $\mathrm{X}_{8}$ & & & & & & & & & & & & & $\begin{array}{l}1.00 \\
0\end{array}$ & $\begin{array}{l}0.924 \\
*\end{array}$ \\
\hline
\end{tabular}

$\mathrm{X}_{1}=$ First count; $\mathrm{X}_{2}=$ Final count; $\mathrm{X}_{3}=$ Speed of germination; $\mathrm{X}_{4}=$ Seedling length $(\mathrm{cm}) ; \mathrm{X}_{5}=$ Seedling dry weight $(\mathrm{mg}) ; \mathrm{X}_{6}=$ Vigour index-I; $\mathrm{X}_{7}=$ Field emergence; $\mathrm{X}_{8}=$ Electrical conductivity; $\mathrm{X}_{9}=48 \mathrm{~h}$ AAT; $\mathrm{X}_{10}=72$ h AAT; $X_{11}=96$ hrs. $X_{12}$ to $X_{15}=$ Germination percentage after $0,2,4,6$ and 8 months of storage 